\title{
親水公園における四季を通した微気象に関する調査研究
}

\section{A Research of Minute Weather Effect of Four Seasons in SHINSUI Park}

\author{
弓削 龍* 畔柳 昭雄** \\ Ryu YUGE Akio KUROYANAGI
}

\begin{abstract}
This research is investigation for improvement of the urban environment using the minute weather effect of SHINSUI Park. The measurement survey was done in SHINSUI Park in Edogawa Ward using the water and green network to SHINSUI Park.

As a result, changing of the minute weather effect in the park by the cycle of the season of the deciduous tree, and having improved SHINSUI Park and minute weather urban in the surrounding became emerged. A way to scatter of the minute weather effect to the urban area in the surrounding, it is important to forest with roadside tree in succession in the park. We aim at improvement of the urban environment by making use of a minute weather formation effect formed around these SHINSUI Park.
\end{abstract}

Keywords: waterfront, SHINSUI park, minute weather effect, land cover, multiple regression analysis キーワード：水辺環境，親水公園，微気象効果，土地被覆，重回帰分析

\section{1.はじめに}

今日, 地球温暖化現象を抑制するため, 低炭素社会の構築が求 められてきている。そのような中で, 東京都の都心部では, 都市 特有のヒートアイランド現象が顕著に発生し, それに起因して乾 燥化や局所的な豪雨等といった都市環境問題が顕在化してきてい る。このように, 都市環境問題は様々な弊害を引き起こし, 悪循 環を促すため, 問題の改善を図ることは急務とされている。

そこで近年，都市気候の改善方法の一つとして自然環境による 気象緩和効果に注目が集まっている。これまで, 気象緩和効果に 着目し，水辺や緑地の気象観測調査を実施した研究は，村川ら $(1988)^{1)}$, 清田ら $(2007)^{2)}$, 尹ら $(1998)^{3)}$ 等, 多くの研究者に より報告されている。しかし, これらの研究は, 都市環境の改善 を図る効果が大きい大規模な水辺や緑地を対象としており, 今日 的な課題の所在を捉えることに焦点を当てたものや，特定の季節 下での検討で終始しているものが多い現状にある。小規模な水辺 や緑地の熱的効果を四季を通して把握した研究は, 深川ら（20 $06)^{4)}$ ，小谷ら $(1996)^{5)}$ によるものがあるが，今後の都市気候の 改善を考える上で, より多くの小規模な水辺や緑地の四季を通し た熱的効果を把握することは重要であると考える。

そこで本研究では, 四季を通した親水公園の有する水辺や緑地 が果たす熱的効果を把握することを目的に, 周辺市街地の気象分 布について実測調查を実施した。その結果から，親水公園による 微気像効果の把握と共に, 測定気温と土地被覆の関係性を定量的 に明らかにし，都市環境改善のための効果を検討する。

\section{2. 調查概要}

調査概要を表 -1 に示す。調査対象地は, 親水公園の整備が進 められている東京都江戸川区を対象とした。現在, 江戸川区では 5 路線の親水公園が開設されているが, 本研究では, 5 路線の親 水公園の中でも人口密度の高い居住域を流下する親水公園を対象 として，一之江境川親水公園を選定した。一之江境川親水公園は，

\begin{tabular}{|c|c|}
\multicolumn{2}{c|}{ 表 -1 調查概要 } \\
\hline 調查対象地 & 一之江境川親水公園(東京都江戸川区) \\
\hline 解析対象日 & 2008年5月15日(春季)、2008年8月9日(夏季) \\
\hline 調査項目 & 2008年11月23日(秋季)、2009年2月9日(冬季) \\
\hline \multirow{2}{*}{ 調査機器 } & サーシ温度、風向·風速、水温、土地被覆、緑量分布 \\
\hline
\end{tabular}

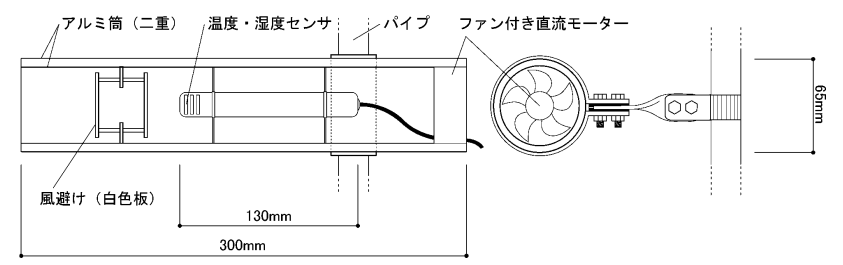

図-1 測定装置 (受感部) 詳細図

水路幅が $2 \sim 4 \mathrm{~m}$ と小規模であり, 公園内の樹木は落葉樹が多 くを占めている。

\section{（1）気象分布の計測方法及び分析方法}

(i ) 周辺市街地における気像観測方法

気象観測調查は, 微気象範囲 ${ }^{6)}$ の測定を行うため, 公園を中 心にした両側縦横に $100 \mathrm{~m}$ を設け， $200 \mathrm{~m}$ 四方の範囲を設定した。 測定点は, 観測範囲内を縱横 20 分割して, $10 \mathrm{~m} \times 10 \mathrm{~m}$ グリッド を基準に 1 グリッド毎に測定地点を決めた。この時, 個人住宅や 工場等で立ち入りが不可能な場所を省くことで合計 $200 ヶ$ 所を設 定した。調查は，円滑に行うために観測ルートを 4 グループに分 け，各ルート同時に約 50 ヶ所で測定を行い，午前 10 時から 2 時 間おきに $12 ， 14 ， 16 ， 18 ， 20$ 時之計 6 回行った。

周辺市街地における気象観測は, 徒歩による移動観測 ${ }^{7)}$ を行い, 計測機器(気温：サーミス夕温度計, 湿度: 高分子抵抗变化型湿 度センサ)を各測定地上 $1.5 \mathrm{~m}$ の高さに取り付け，各測定点で約 30 秒間停止した後に, メーカーにより指示があったプローブ中 のセンサの作動を考慮して，さらに 10 秒間経過した後に，温度・

${ }^{*}$ 日本大学大学院理工学研究科海洋建築工学専攻 ${ }^{* *}$ 日本大学理工学部海洋建築工学科 


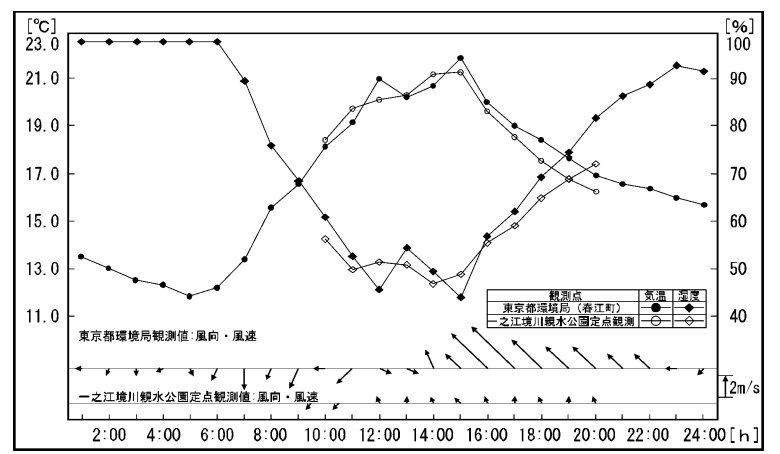

図一2 春季の観測日における気象状況（2008 年 5 月 15 日）

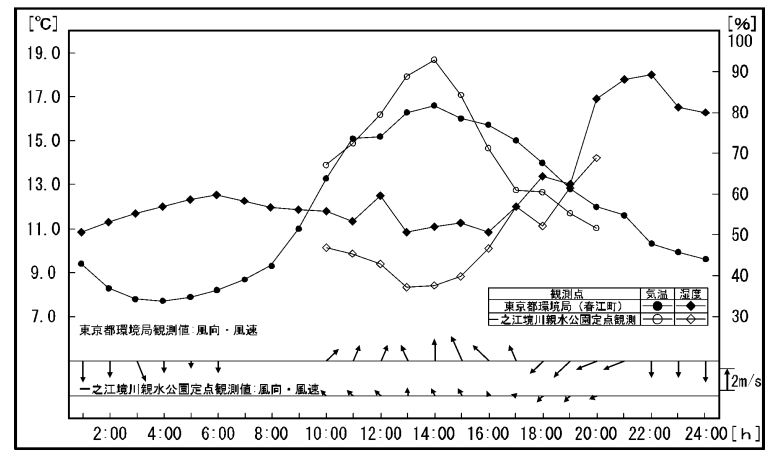

図-4 秋季の観測日における気象状況（2008 年 11 月 23 日）

湿度の瞬間值を読み取り，風向の瞬間値も共に測定した。

測定装置の受感部の詳細を図ー 1 に示す。観測時における日射 の影響を考慮して，アルミ板を内外部に巻いた二重筒内に受感部 を搭載した。受感部は直接風を避けるために自作の自然通風式シェ ルターを装着している。強制通風装置の風速は約 $4 \mathrm{~m} / \mathrm{s}$ である。

（ii）気温分布と土地被覆割合による重回帰分析

調査対象範囲の土地被覆は, 住宅詳細図及び航空写真を用いて 判読し, その判読したものの整合性を取るため, 現地で土地被覆 の確認を行った。その土地被覆デー夕を基に, 各測定点を中心と した直径 $50 \mathrm{~m}$ 範囲内の土地被覆割合を算出し, 重回帰分析によ る解析を行った。ここで直径 $50 \mathrm{~m}$ 範囲内とした理由は, 観測点 からの距離に伴う気温と土地被覆との重相関係数が安定すると報 告されている北山ら $(1992)^{8)}$ の結果を引用している。

\section{（2）観測日における気象概要}

各季節の観測日に打ける気象概要を図 $-2,3,4,5$ に示 す。春季, 夏季, 秋季の天候は晴れであったが, 冬季の天候は曇 りであった。

調查対象地に近接する東京都環境局（大気污染常時測定局：春 江町）が測定した気象状況と公園内で測定した気象状況を比較す ると, 較差が生じているものの, 概ね同様の変動傾向を示してい る。

全季節の気温及び湿度の傾向は, どの季節も日中の $13 \sim 15$ 時 台でピークに達し, それを境に気温は低下し, 湿度は上昇するこ とが確認できる。また, 風速を見ると, 公園内の観測データより 大気污染局の観測デー夕の風速が大きくなっている。観測日にお ける大気污染局の平均值は, どの季節も $1.5 \sim 3.0 \mathrm{~m} / \mathrm{s}$ の範囲内 であったため, 穏やかな気象状況であったといえる。

\section{3. 結果及び考察}

\section{（1）周辺市街地における気温分布}

各季節の周辺市街地における気温分布を図-6，7，8，9に 示す。これより, 日中の気温がピークに達し, 都市環境問題が顕 著に見られる 14 時台における各季節の気温分布を考究する。

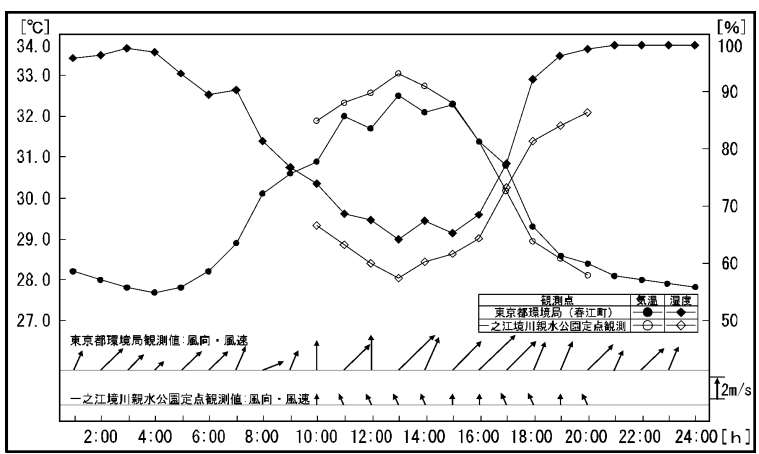

図－3 夏季の観測日における気象状況（2008 年 8 月 9 日）

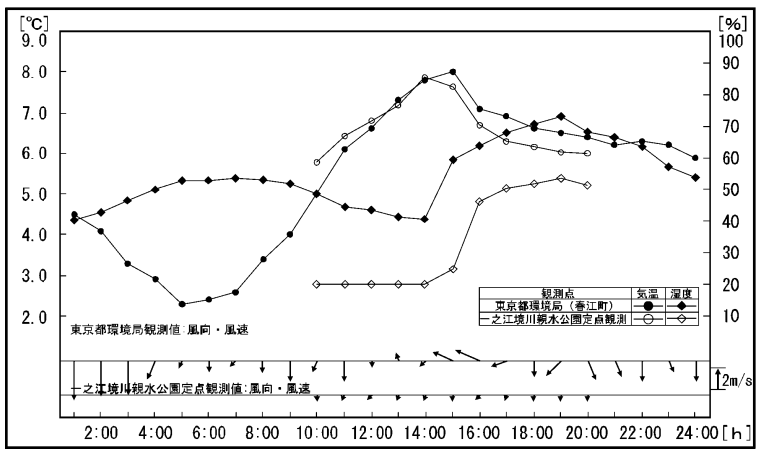

図－5 冬季の観測日における気象状況（2009 年 2 月 9 日）

春季及び夏季を見ると，公園内の気温分布は，両季節共に市街 地よりも気温が低く保たれており，この公園内に滞留している冷 気は，公園と直交する道路に沿って広がる傾向を示している。一 方，市街地の気温分布は，両市街地共に公園から遠ざかるにつれ て気温が上昇し, 特に高密度に住宅が立地する街区で公園内と比 べて気温差が大きく, その差は春季で最大 $1.6^{\circ} \mathrm{C}$, 夏季で最大 2.2 ${ }^{\circ} \mathrm{C}$ と大きくっていることがわかる。しかし, 夏季は, 西側市街 地の大規模な住宅が立地する測定点付近で, 公園と同様, 気温が 低くなる傾向が見られる。

秋季及び冬季を見ると，公園内の気温分布は，両季節共に市街 地よりも気温が上昇する傾向にあり，冬季は，春季及び夏季と同 様, 公園と直交する道路に沿って広がる傾向となっていることが わかる。しかし, 秋季は, 西側市街地に見られる低温域と隣接し ており, 公園内の気温分布は複雑な形状となっている。一方, 市 街地の気温分布は, 両季節共に公園から遠ざかるにつれて気温が 低下する傾向にあり, 公園内との気温差は両季節共に最大 $1.0^{\circ} \mathrm{C}$ となっている。しかし, 秋季に限り, 局所的に気温が高くなる傾 向を示していることがわかる。

以上より, 春季及び夏季では, 公園内や街路樹が植栽されてい る測定点付近において低温傾向を示し, また, 公園から離れた街 区や高密度に住宅が隣接する街区において高温傾向を示すことが わかった。これらは, 水面による気化熱, 樹木の樹葉による蒸発 散や日射遮蔽が泠源として作用しており，人工被覆面による輻射 熱や人工排熱等が熱源として作用していると考えられる。

一方, 秋季及び冬季では, 公園内や高密度に住宅が隣接する街 区に打いて高温傾向を示し，公園から離れた街区や街路樹が植栽 されている測定点付近において低温傾向を示すことがわかった。 公園内の気温は, 公園内の落葉樹が落葉したことで, 樹葉による 蒸発散や日射遮蔽により冷源としての作用が減少し, 水面が熱源 として作用したことで気温が上昇したと考えられ，市街地の気温 は, 季節の変化により, 日射の角度が変化したことで輻射熱等の 熱源としての作用が減少し, 気温を低下させたと考えられる。

（2）親水公園からの距離による気温変化 


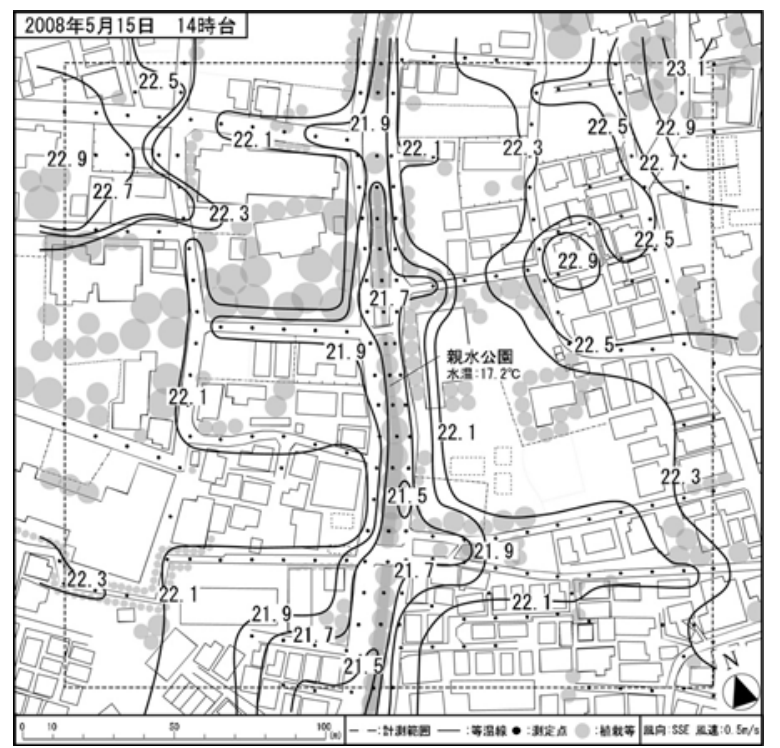

図一6 春季の周辺市街地における気温分布

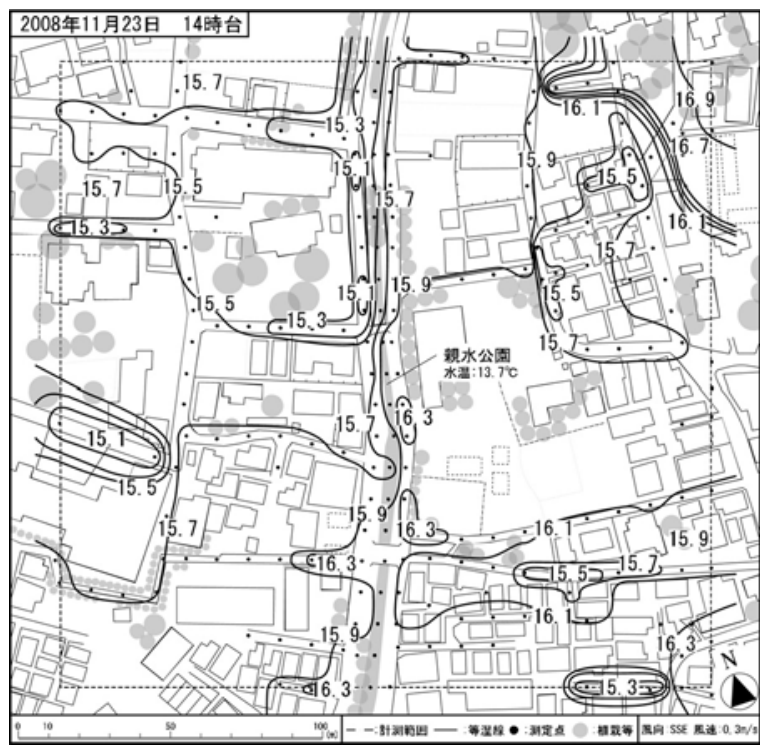

図－8＼cjkstart秋季の周辺市街地における気温分布

各季節における親水公園からの距離による気温変化を図 -10,

11，12，13 に示す。これより公園からの距離と測定気温の関係 性を考究する。

春季及び夏季の結果では, 公園内の平均気温と両市街地の平均 気温を比較すると, 公園から遠ざかるにつれて両市街地の平均気 温が上昇していることが確認できる。しかし，夏季に限り，西側 市街地で公園内の平均気温と同じ $32.9^{\circ} \mathrm{C}$ となっており, 約 $60 \mathrm{~m}$ 地点から急激に測定気温が低下することがわかる。

秋季及び冬季の結果では, 公園内の平均気温之両市街地の平均 気温を比較すると，多少の気温差しか見られないが，公園内より も両市街地の平均気温が低下していることが確認できる。

以上より, 各季節の親水公園からの距離による気温変化は, 春 季及び夏季に揸いて, 公園から遠ざかるにつれて気温が上昇して おり，秋季及び冬季において，気温が低下していることがわかる。 しかし, 親水公園からの微気像効果がじの範囲まで影響している か明確にすることは困難である。そこで, 一つの目安として, 村 川ら (1988) ${ }^{1)}$ により報告された, 気温の変化傾向を表す回帰曲 線が両市街地内の平均気温に達するまでの距離を影響範囲 ${ }^{9)}$ と仮 定するならば，春季では東側市街地で $60 \mathrm{~m}$, 西側市街地で $50 \mathrm{~m}$,

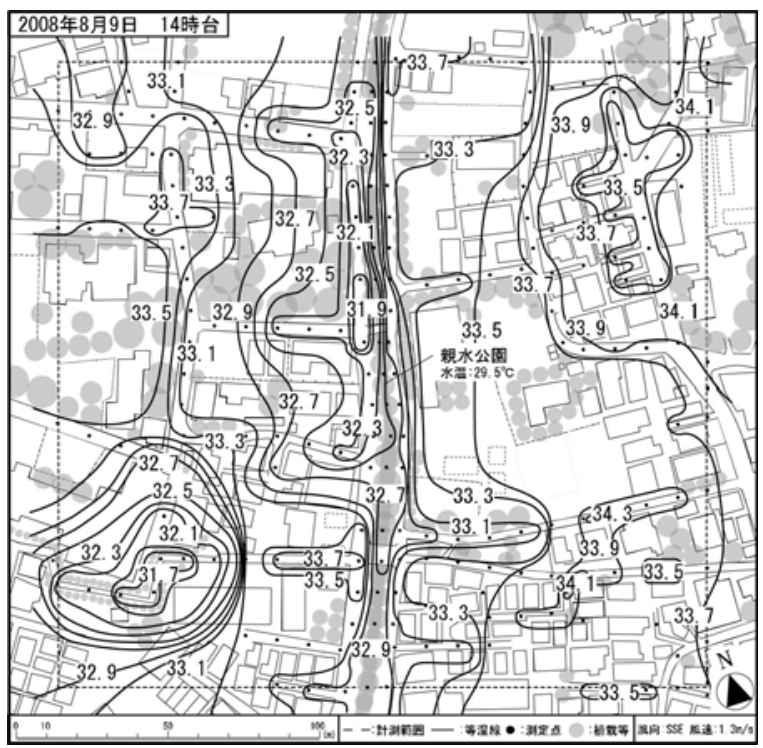

図-7＼cjkstart夏季の周辺市街地における気温分布

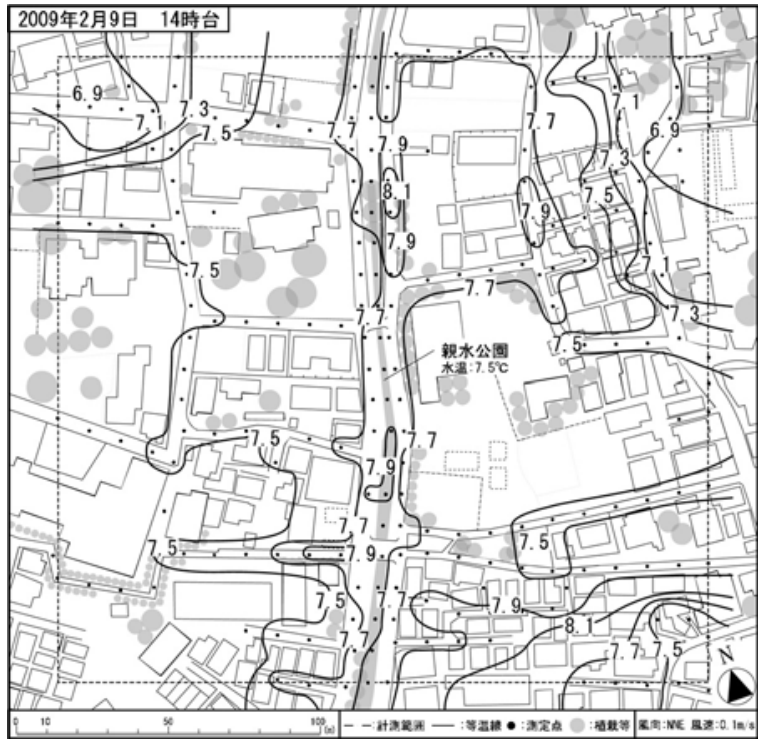

図-9 冬季の周辺市街地における気温分布

夏季では両市街地共に $50 \mathrm{~m}$ ，秋季では東側市街地で $90 \mathrm{~m}$ ，西側 市街地で $50 \mathrm{~m}$, 冬季では, 東側市街地で $50 \mathrm{~m}$, 西側市街地で $60 \mathrm{~m}$ の範囲まで影響が及んでいると考えられる。

\section{（３）地表面被覆が気温形成に及ぼす影響}

各測定点における測定気温の気温形成要因を定量的に把握する ため，都市気温に影響を及ぼしている要因として考えられる測定 点の土地被覆の影響について，ステップワイズ法による重回帰分 析を行った。重回帰分析は，実測気温を従属変数に，水面率，緑 被率, 裸地率, 人工被覆率を説明変数として分析を行った。

重回帰分析の結果を表- 2 に示す。各季節の重回帰分析の結果 を見ると，重相関係数は，0.25〜0.69 の範囲内を推移しており， 全体的に低い傾向にある。

一方，各季節の標準偏回帰係数を見ると，春季は水面率と緑被 率，夏季は水面率と緑被率，人工被覆率において統計的有意性が 見られた。その中でも水面率, 緑被率の項目は両季節共に負の值 を示し，特に春季の水面率と実測気温との間には他の項目よりも 関係性（一0.57）が見られる。また，夏季の人工被覆面は正の值 を示していることがわかった。

秋季は，水面率と緑被率，裸地率，冬季は水面率において統計 


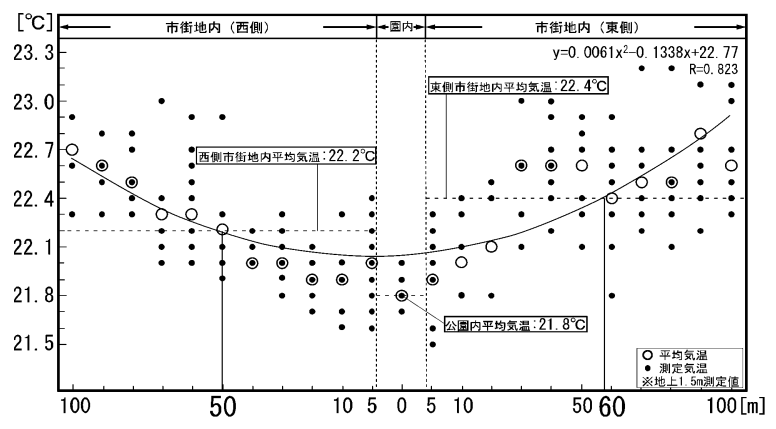

図－10＼cjkstart春季の親水公園からの距離における気温変化

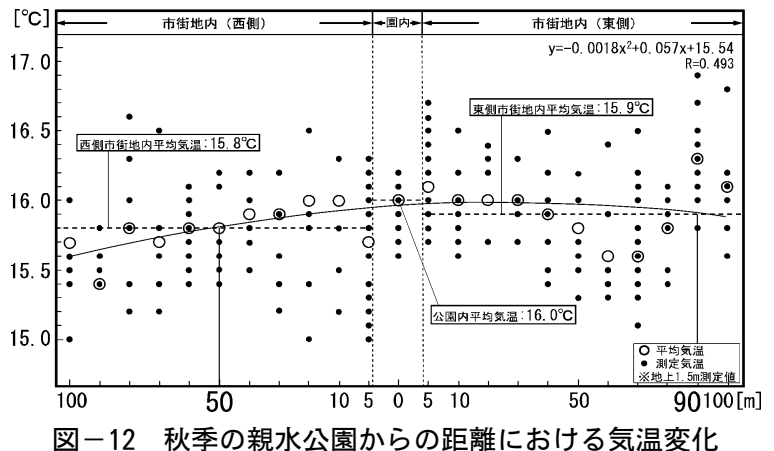

的有意性が見られ, 両季節共に水面率で正の值を示し, 特に冬季 の水面率と実測気温との間には他の項目よりも関係性 (0.48) が 見られる。また, 秋季における緑被率と裸地率は負の值を示すこ とがわかった。

このように，公園内の水面は，春季及び夏季において負の值を 示し，秋季及び冬季においては正の值を示すことがわかった。ま た，緑被地はどの季節においても負の值を示すことがわかった。 以上より, 公園内の水面は, 春季及び夏季で気温を低下させ, 秋季及び冬季で気温を上昇させており, 緑被地はどの季節におい ても気温を低下させていることがわかる。このことから，小規模 な水面及び緑被地でも気温形成に影響を与えていると考えられる。

\section{4.おわりに}

本稿では, 四季を通した親水公園の有する水辺や緑地の微気象 形成効果を捉えると共に, 測定点の気温形成要因を検討した。そ の結果から得られた知見を以下に示す。

(1) 親水公園内は, 春季及び夏季で水辺や樹木の冷源作用により低 温域が形成されており，秋季及び冬季では，水辺の熱源作用に 加え, 樹木の泠源作用が減少したことにより, 高温化すること がわかった。

(2)親水公園内に形成される微気象効果は, 公園と直交する道路に 沿って拡散していることがわかる。

(3)親水公園からの微気像効果範囲は, どの季節も両市街地に約 $50 \mathrm{~m}$ まで効果を及ぼすことがわかった。

(4)重回帰分析の結果より, 水辺は春季及び夏季において冷源とし て作用し, 秋季及び冬季において熱源として作用することが確 認できた。また，緑被地においては，どの季節においても冷源 として作用することが確認できた。

今回の調査では, 親水公園に植栽されている落葉樹の季節によ る状態変化が, 公園内の微気象効果を変化させ, 親水公園内及び 周辺市街地の微気象を向上させていることが明らかとなった。ま た, 周辺市街地へ微気象効果を拡散させる方法としては, どの季 節においても親水公園と直交させて街路樹を植栽させることが重 要であることを捉えた。

以上の結果から, 中小河川や運河等を親水公園として整備する

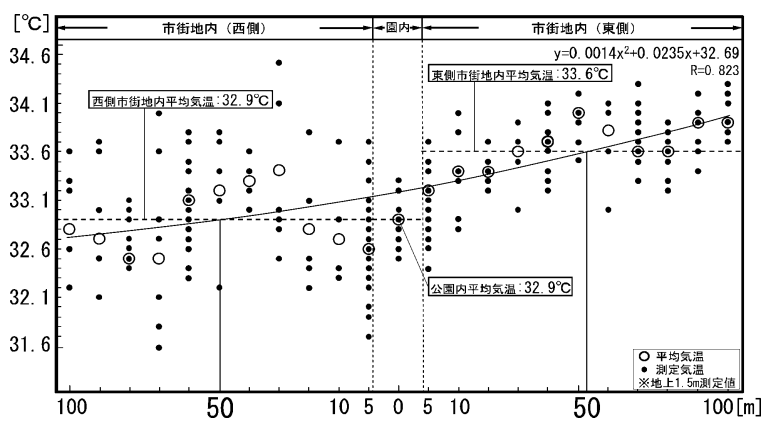

図-11 夏季の親水公園からの距離における気温変化

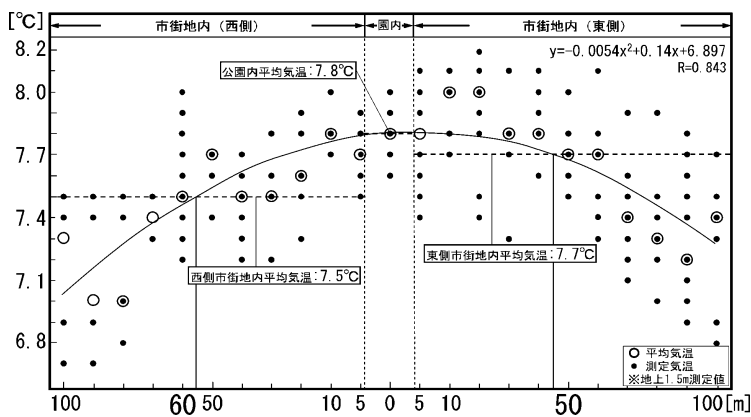

図-13 冬季の親水公園からの距離における気温変化

\section{表-2 重回帰分析結果}

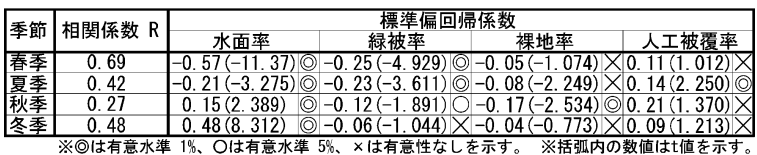

上で都市環境問題の改善を図るためには，各季節の微気象条件を 考慮し，水面の規模や樹木の樹種を決定することが有効な整備に なると考えられる。しかし，都市居住者にとって身近な自然環境 は, 景観的配慮やレクリエーションの場としての機能等も提供し なければならない(10)。そのため，今後，親水公園を整備する際に は，景観の形成や都市の環境問題の改善等を含めて整備方針を検 討する必要があると考えられる。

\section{補注及び引用文献}

1 ）村川三郎ほか（1988）：都市内河川が周辺の温熱環境に及ぼす効果に関す る研究 : 日本建築学会計画系論文集第 393 号, 25-34

2) 清田忠志ほか（2007）：都市域におけるヒートアイランド現象の緩和対策 に関する研究一その 2 広島市の夏季の都市気温と土地被覆との関係に対す る重回帰分析－：日本建築学会環境系論文集第 614 号, 57-63

3 ）尹 龍漢ほか（1998）:都市における公園内外の気温分布特性について：ラ ンドスケープ研究 61(5), 769-772

4 ）深川健太ほか（2006）：開発が進む地方都市の田围・ため池周辺と市街地 の四季を通した気温形成状況の比較 : 日本建築学会環境系論文集第 605 号, 95-102

5 ）小谷幸司ほか（1996）：臨海都市における気温分布と緑地の気温低減効果 に関する研究：日本都市計画学会学術研究論文集第 31 回, 85-90

6 ）新田信三・東集成・石井昭夫（1981）：環境緑化における微気象の設計

7 ) 移動観測に伴う時刻補正は測定点を重複させ, 測定点の経時変化を求める と共に，公園内の定点における気像データとの照合を図ることで補正值を 算出した。また，各計測機器による器差については，事前の測定により補 正を行っている。

8 ）北山広樹ほか（1992）：都市における土地利用と気温分布に関する調査研 究：日本建築学会大会学術講演梗概集, 1403-1404

9 ）本研究は，調查対象としている水路が小規模であり，影響範囲が小さくな ると考えることができる。村川らの報告結果を引用し，本研究の水路規模 で影響範囲を算出すると, 影響範囲は約 $20 \mathrm{~m}$ となる。この指標を考慮して, 本研究で定めている微気像範井の影響を検討すると, 両市街地の調查範囲 $100 \mathrm{~m}$ が適切であると考えられるため, 本研究では影響範囲の判定を $100 \mathrm{~m}$ と設定した。

10）日本建築学会（2007）：ヒートアイランドと建築・都市一対策とビジョン と課題一 